\title{
A magyarországi zarándokutak turisztikai kapcsolódásai és üzemeltetési modelljei
}

\author{
Szerzők: Mártonné Máthé Kinga ${ }^{1}$ - Simonyi Norbert ${ }^{2}$
}

Az elmúlt 30 évben jelentôs növekedés ment végbe a nemzetközi zarándokturisztikai piacon. Ennek két mozgatórugója van: egyrészt nô a keresztény és muszlim vallást gyakorlók száma, másrészt nô azok száma is, akik utazásuk során vallási elemeket építenek be az útitervükbe. Ez a nemzetközi tendencia Magyarországon nem figyelhetô meg, a tanulmány többek között ennek a kérdésnek a megválaszolására tett kísérletet. E mellett teljes körüen feltérképezte a turisztikai szolgáltatásokkal kiegészített hazai zarándokút hálózatot, definiálta a zarándoklatok turisztikai szerepét, valamint lehatárolta a zarándok és a turista közös jellemzőit. A Magyar Turisztikai Ügynökség számára "A magyarországi zarándokutak turisztikai kapcsolódásai és üzemeltetési modelljei" kutatást a Századvég Alapítvány 2017 decemberében készítette el szoros együttmüködésben az Aktív és Kulturális Turizmusért Felelős Igazgatóság kollégáival.

Kulcsszavak: zarándokutak, zarándokturizmus, zarándokszállás, elvonulás, turizmus, katolikus.

\section{Bevezetés}

„Hát nekem a zarándokútról pont nem a turizmus jut eszembe. De aki zarándokúton van, az nyilván látja a tájnak a szépségeit, meg a történelmet, a templomokat, látnivalókat, de... szerintem ez több annál, mint turizmus." ${ }^{3}$

A zarándokturizmus a turisztikai ágazaton belül évek óta ismert, érdeklődéssel vegyes, ám kissé fenntartásokkal kezelt altermék, melyet a kutatások terén sem támasztott alá semmilyen egzakt adatbázis vagy gazdaságossági számítás. Jellemzően a kulturális turizmus altermékeként, niche termékként kezeli a szakma a zarándokturizmust, annak keresleti és/vagy kínálati elemei és igényei azonban mindezidáig nem kerültek feltárásra. Nem került felmérésre az sem, vajon ki a hazai zarándokturista, milyen fogyasztói profillal rendelkezik, és mekkora volument képvisel a teljes turisztikai palettán. Az is hiányosságként volt értelmezhetô, hogy a szolgáltatói oldalt kik képviselik, áll-e üzleti megfontolás a vállalkozások mögött vagy csupán karitatív cél vezérli a zarándokturisztikai szolgáltatót.

Felmerül a fenntarthatóság kérdése, és az is, hogy az utakat múködtető nagyrészt társadalmi

\footnotetext{
1 igazgató, Magyar Turisztikai Ügynökség, Aktív- és Kulturális Turizmusért Felelős Igazgatóság, kinga.martonnemathe@mtu.gov.hu

2 vezető szakértő, Magyar Turisztikai Ügynökség, Aktív- és Kulturális Turizmusért Felelős Igazgatóság, norbert.simonyi@mtu.gov.hu

3 Az idézetek a zarándokutak üzemeltetőinek és a fókuszcsoportos kutatásban részt vevőknek a véleményeit tartalmazza.
}

célú szervezetek képesek-e a professzionális üzemeltetésre önköltségen, illetve életben maradnának-e az utak és a szervezetek tisztán piaci körülmények között?

A zarándokutak pontos, településszintú helyszínei sem kerültek eddig meghatározásra, a tanulmány erre is kísérletet tesz.

Komoly dilemma a szakmában a zarándokturista valós motivációjának felmérése. Ennek kettős oka van. Egyrészt a turisztikai utazások vallási/világi jellegét nem kizárólag a helyszín határozza meg, hanem inkább az utazó indíttatása (motivációja). Így a komoly vallásos utazó számára az adott hely "szent”, ahol teljesülhetnek lelki/ hitéleti elvárásai. Ezek a helyek lehetnek évezredes történelmi célpontok, de szolgálhat vallási turizmus céljául olyan célpont is, melyet a megfelelő közösség „szentesít"4. Másrészt a motivációs kutatások jellemző módszertana a zarándokturizmus esetén csak részlegesen használható, hiszen a zarándok ritkán posztol a közösségi oldalakon, lelki indíttatását inkább magában tartja, mintsem hogy kibeszélje. A célcsoport introvertáltabb, mint az átlagos turista.

A zarándokturizmus esetében az út sokszor ugyanolyan fontos, esetenként akár fontosabb is, mint az úti cél elérése. Az időfaktort tekintve az út körülbelül fele, kétharmada is lehet annak az időnek, amit a zarándoklatra szán az utazó, a kegyhelyen töltött idő nemritkán csupán az összes utazásra szánt idő egyharmada (1. ábra). Elmondható tehát, hogy egy zarándoklaton tulajdonképpen maga az út és az út során a cél eléréséig meg-

4 Jancsik András (Pannon Egyetem) gondolatai a RECULTIVATUR projekt kapcsán. 
tapasztalható lelki fejlődés a fontos, nem az adott turisztikai desztináció élménykínálata.

\section{1. ábra}

A zarándoklat magyar szakasza teljesítésének átlagos időtartama (nap)

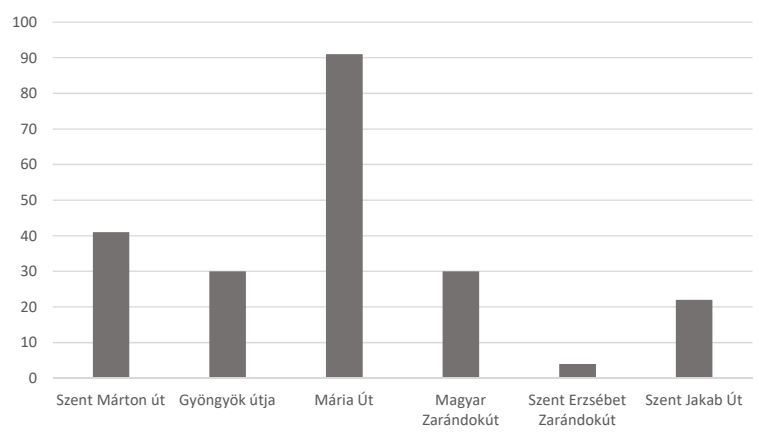

Forrás: saját szerkesztés

Problémát jelent továbbá, hogy a zarándokturizmus nemzetgazdasági szintû́ turisztikai hozadéka forintban nehezen mérhető. A hazai zarándokutak bevétele és forgalmi adatai csak minimálisan jelentkeznek a turisztikai statisztikákban, a piac teljesen szabályozatlan, illetve belsố ellentétek is nehezítik a múködését. A zarándokszállások szabályozása, az idegenvezetési minősítés jogi helyzetének tisztázása a zarándokút-vezetők körében, valamint az egységes adatbázis és minősítési rendszer kialakítása mind-mind megoldandó probléma. Az utak többsége esetében a bevételszerkezetet legnagyobb mértékben hazai, elenyészó mértékben külföldi, EU-s pályázatokra, állami vagy önkormányzati költségvetési támogatásokra építik, illetve kisebb - lényegében elhanyagolható - mértékben személyes támogatásokra, egyesületi tagdíjra, zarándoklatok többnyire nonprofit részvételi díjára, SZJA 1\%-ra, tájékoztató füzetek, könyvek, vagy ajándéktárgyak eladásából származó bevételekre. Érdekesség, hogy az egyházi anyagi támogatás nem jelenik meg a zarándokutak múködtetése kapcsán.

A tanulmány egyértelmúen rámutat arra, hogy ez az üzemeltetési modell gyakorlatilag fenntarthatatlan, a fent említett problémák megoldásában a Magyar Turisztikai Ügynökségnek (MTÜ) szerepet kell vállalnia a turisztikai szempontok érvényesítése, a szabályozás kidolgozása és a fenntarthatóság megvalósítása érdekében. Kérdés, hogy az MTÜ-nek milyen mélységig kell ezt megtennie a zarándokutak turisztikai hasznosításának elősegítésében, hogy megvalósuljon a zarándokutak turisztikai csomagként történó értékesíthetősége, s ráadásul oly módon, hogy a zarándoklatok szakrális és lelki elemei ne sérüljenek.

\section{Módszertan}

"A tagok nagy része katolikus, de van közöttünk református is, és egyébként pedig például ma is lesz zarándok-imánk, (...) katolikus templom, ugyanakkor eljönnek protestánsok is vagy „keresők" is."

A primer kutatást elsősorban személyes, illetve fókuszcsoport interjúkra, másodsorban a szálláshelyeken kiküldött kérdôivekre alapozva végeztük el. Az adatközlők - mind a zarándokút-fenntartók, mind a zarándokút-független megszólalók, illetve a turisztikai szakértők és a fókuszcsoportokon részt vettek - a felmerülő kutatói kérdésekre leginkább megérzések, benyomások alapján, egyes esetekben egymásnak ellentmondóan, olykor személyes érintettségük hatását is éreztetve, tudtak érezhetốen erôs emóciókkal reagálni. Továbbá a rendelkezésre álló vagy a felkutatott kevés, jellemzően önbevalláson alapuló statisztika és egyéb tényadat is adott esetben elavult volt, vagy kiderült, hogy szintén megérzések alapján készült. A kutatás nemcsak a katolikus zarándoklatokra fókuszált, a vizsgálatba bevonásra kerültek a protestáns felekezetek hajlandóságai is a zarándoklatokon való részvételre.

\section{Zarándok vagy turista}

„Itt a kulturális emlékekre is azér' nagy hangsúly van fektetve. Be vannak mutatva. (...) Jáki templom, aztán megyünk tovább."

A szélesebb körben elterjedt vélemény szerint a két profilú utazó nagyon hasonló, majdhogynem ugyanaz, hiszen a zarándok és a turista szerepe összefonódik. Bár szükségszerúen különbözőek valamilyen szinten, ám mégis egy egységes és szétválaszthatatlan jelenségként lépnek fel. Ez a megközelítés elsősorban arra épít, hogy mind a zarándokok, mind pedig a turisták - kívülrôl nézve - többé-kevésbe azonos módon utaznak, fogyasztanak és veszik igénybe az infrastruktúrát.

Ezzel szemben foglalnak állást azok, akik - éppen a motivációk eltérô jellege miatt - azt állítják, hogy a zarándokok nem turisták (1. táblázat). Ebben az értelemben a mély szakrális motiváció által vezérelt turistákat megkülönböztetik azoktól, akiknek a rekreáció, az élmény vagy éppen a tanulás a motivációjuk. Általánosságban ezt a nézetet a vallási szervezetek részesítik előnyben. 
Múhely

Zarándok vagy turista

1. táblázat

Szakrális Jellege

_mozgatható potméter"

Világi

\begin{tabular}{|c|c|c|}
\hline Zarándok & Zarándok-Turista & Turista \\
\hline Lelki motiváció & Szellemi motiváció & „Testi" motiváció \\
\hline Szubjektivitás & $\begin{array}{l}\text { Ma a vallási/lelki motiváció többnyire nem } \\
\text { tisztán, nem közvetlenül jelentkezik, de nagyon } \\
\text { sokunkban jelen van }\end{array}$ & Objektivitás \\
\hline Az utazás vége a cél & Az egész folyamat a cél & Az utazás a cél \\
\hline Lelki profit & Önfenntartás & Materiális profit \\
\hline "Hagyományos" utazás & Posztmodern turizmus & Modern turizmus \\
\hline Fogyasztásösztönzés, belsô & Külsô-belső fogyasztásösztönzés & Fogyasztásösztönzés, külső \\
\hline Nem vagyok turista érzés & Utazó érzés & Turista vagyok érzés \\
\hline Önmagával történô megosztás & Személyes megosztás & Közösségi hálón történô megosztás \\
\hline Parókia & Tematikus szálláshely & Szálloda \\
\hline Lelki termék & $\begin{array}{l}\text { Vegyes termékek: sportos zarándoklat, } \\
\text { borkultúra E vallás stb. } \\
\text { Istenes versek nyomában - kulturális tematikus út } \\
\text { Személyes részvétel erösitése- speciális } \\
\text { idegenvezetés hívóknek } \\
\text { Lelki wellness vezetövel vagy „rávezetve” } \\
\text { Böjt és elmélyülés - biotermékek } \\
\text { Ismeretlen tanítások ötvözése }\end{array}$ & Turisztikai termék \\
\hline A divat nem játszik szerepet & Fontos a divat szerepe & Fontos a divat szerepe \\
\hline Élmény & Élmény & Pihenés \\
\hline Bárki & $\begin{array}{l}\text { Nagyrészt egyedülálló nô, vagy házaspár, } \\
\text { középkorú } \\
\text { értelmiségi }\end{array}$ & Bárki \\
\hline Nem költ & Keveset költ & Átlagosan költ \\
\hline Inkább szervezetten utazik & Önállóan szervezi útját & Inkább szervezetten utazik \\
\hline Nem költ & Relikviákra költ & Ajándéktárgyakra költ \\
\hline Nincs igénye & Kisigényü & Nagyigényú \\
\hline Nincsenek elvárásai & Vannak elvárásai a lelki feltöltekezés terén & $\begin{array}{l}\text { Vannak elvárásai a testi } \\
\text { feltöltekezés terén }\end{array}$ \\
\hline Utazó & "Lelki" ökoturista & Turista \\
\hline $\begin{array}{l}\text { Lelki vendéo: ajándékként értelmezi } \\
\text { a lelki feltöltekezést, klasszikus } \\
\text { értelemben vallásos, a hitben látja } \\
\text { a lényeget }\end{array}$ & $\begin{array}{l}\text { "lelki" MICE vendég: szolgáltatásként értelmezi } \\
\text { a lelki feltöltekezést } \\
\text { nem klasszikus értelemben vallásos, az } \\
\text { elvonulásban látja a lényeget }\end{array}$ & $\begin{array}{l}\text { Vendég: szolgáltatásként értelmezi } \\
\text { az utazást } \\
\text { nem vallásos, a pihenésben látja a } \\
\text { lényeget }\end{array}$ \\
\hline Látens & Mérhetố & Mérhetô \\
\hline $\begin{array}{l}\text { Attrakciófejlesztéssel nem } \\
\text { befolyásolható }\end{array}$ & Attrakciófejlesztéssel nagyon befolyásolható & $\begin{array}{l}\text { Attrakciófejlesztéssel közepesen } \\
\text { befolyásolható }\end{array}$ \\
\hline $\begin{array}{l}\text { Szoloáltatásfejlesztéssel nem } \\
\text { befolyásolható }\end{array}$ & Szolgáltatásfejlesztéssel közepesen befolyásolható & $\begin{array}{l}\text { Szolgáltatásfejlesztéssel nagyon } \\
\text { befolyásolható }\end{array}$ \\
\hline Hit & Belsố élmény & Külső élmény \\
\hline Demonstrálni akarják hitüket & Demonstrálni akarják tudásukat & $\begin{array}{l}\text { Demonstrálni akarják anyagi } \\
\text { lehetóségeiket }\end{array}$ \\
\hline Szolidaritás és közösségérzés & Egyéni, családi érzés & Közösségérzés \\
\hline $\begin{array}{l}\text { Egy sajátos csoportnak - kiélezett } \\
\text { verseny nélkül }\end{array}$ & USP termék, erôs verseny & Átlagtermék, kiélezett verseny \\
\hline Vallásosság & Hit-tudásvágy & Pihenés \\
\hline $\begin{array}{l}\text { Az utazás során a nehézségek } \\
\text { fontosak }\end{array}$ & Az utazás során a nehézségek elfogadhatóak & $\begin{array}{l}\text { Az utazás során a nehézségek nem } \\
\text { elfogadhatóak }\end{array}$ \\
\hline A tematika fontossága & A tematika fontossága & A tematika elhanyagolható \\
\hline
\end{tabular}

Forrás: saját szerkesztés 
Smith ezeket a megközelítéséket részben szintetizálva úgy vizsgálta a kérdést, hogy egy skála egyik végpontjára a zarándokot, míg a másikra az általános turistát tette, és azt mondta, hogy ezek között rengeteg kombinációs lehetôség van, ahol a szakrális és a világi értékek párhuzamosan képviseltetik magukat. Ezt alapul véve Schlehe úgy gondolta, hogy az utazók egyik kategóriából könnyen válthatnak a másikba. Vagyis a zarándokok nagy része először teljesíti a rituális gyakorlatokat, majd utána kisétál a tengerpartra, hogy felfrissüljön. Igy tehát elôször a vallási, majd pedig a rekreációs kategóriába sorolható. Ennek inverzeként tekinthetünk arra, amikor egy turista meglátogat egy dicsó múlttal rendelkező desztinációt és a hely szelleme által megihletődve szakrális jellegú cselekedetekbe merül.

Így a turistából könnyedén válhat vallási turista. Az átfedés abban is megmutatkozik, hogy az országok nagy részében a turisztikai statisztikák a vallási turizmust gyakran a kulturális turizmussal együtt mérik, így kevés önálló adat áll a rendelkezésünkre.

\section{Kínálati oldal: a hazai zarándokutak általános bemutatása}

"Azzal tudsz (missziózni), hogy csinálsz zarándoklatokat és ott valaki elkapja az embereket és akkor annak van következménye, mert aki, mit tudom én, zarándokolt, azt elhívjuk egy tanfolyamra, amelyen megismeri jobban, hogy miról is szól a kereszténység."

A hazai zarándokutak teljes hossza megközelitốleg $4829 \mathrm{~km}$, amely 743 esetben halad át valamely magyarországi településen (2. ábra). A kutatás alatt még közel sem ért véget az utak fejlódése, további (több mint ezer km-t kitevő) szakaszok várnak kiépítésre.

A Magyarországról is elérhetó teljes úthálózat hossza (a magyarországi szakaszokkal együtt) nehezebben meghatározható. Az utak honlapján, kiadványaiban elérhetố leírások és térképek alapján megközelítőleg 8130 km-nyi szakasz érhető el, ugyanakkor több út leírása is jelzi, hogy valójában azok sokkal hosszabbak. Míg például a Szent Márton Út honlapja és elérhetó leírásai a külföldi szakaszokkal együtt mindössze $765 \mathrm{~km}$-t foglalnak magukban, addig a fó útvonala $2500 \mathrm{~km}-\mathrm{t}$ tesz $\mathrm{ki}$ Szombathely és Tours között, alternatív útvonalai pedig önmagukban $4000 \mathrm{~km}-\mathrm{t}$ - a szakaszos jelzettség miatt azonban az út még nem tekinthetó késznek (bár vállalkozó kedvú zarándokok számára járható). A Szent Jakab Út és a Gyöngyök útjának egyik ága (elviekben) közvetlen összeköttetésben van Santiago de Compostelával.

\section{Zarándokutak magyarországi szakaszának hossza $(\mathbf{k m})$}

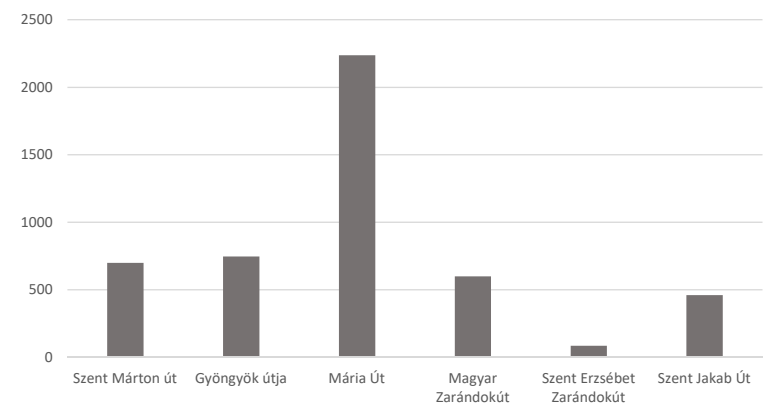

Forrás: saját szerkesztés

\subsection{SZENT MÁRTON ÚT}

A fô európai útvonal (Szombathely - Tours: Magyarországon, Szlovénián, Olaszországon és Franciaországon keresztül) - a fenntartó szerint - megközelítóleg $2500 \mathrm{~km}$ hosszú, míg a teljes európai úthálózat megközelítóleg $4000 \mathrm{~km}$-es. A fó útvonal Magyarországon és Franciaországban teljesen kiépített, jelzett, a szálláshelyek rendelkezésre állnak, gazdag információs anyag és önkéntes háttér segíti az úton lévőket.

Magyarországon a Szent Márton Út teljes hossza körülbelül $700 \mathrm{~km}$, amelyből a fó útvonal mindössze közel 100 km-t tesz ki. Az északi rövid útvonal Szombathely és Rajka között hozzávetőlegesen $170 \mathrm{~km}$, a Pannonhalmát is érintó hosszabb útvonal megközelítőleg $230 \mathrm{~km}$. Két önálló Szent Márton Út (,kör") is található még az országban, amelyek nem csatlakoznak rá a Szombathelyet érintố szakaszokra: az Alföldi Szent Márton Út (Tiszapüspöki - Kunszentmárton) és a Via Divide Caritatem - Szent Márton-út Baranyában (Pécs Pécs). Mindkét útvonal megközelítőleg 100-100 km hosszú.

\subsection{SZENT ERZSÉBET ÚT}

A Sárospatakon Szent Erzsébet születésének 800. évfordulóján, a Szent Márton Út mintájára 2007ben létrejött Szent Erzsébet Út Alapítvány célja, hogy „„̈sszekösse az európai Szent Erzsébet emlék- és tiszteleti helyeket, s létrehozzon egy olyan zarándokutat, amely megerôsíti a szellemi és lelki összetartozást, és fizikai valóságában is végigjárható utat jelöl ki"5. A zarándokút 2011 óta köti öszsze Sárospatakot és Kassát.

5 https://www.szenterzsebetut.hu/ 
Az út egyelőre Magyarország legrövidebb zarándokútja a hat közül. Eddigi egyetlen szakasza mindössze 7 települést érint Magyarországon, megközelítóleg 86 km hosszan, és még 4-et Szlovákia területén, $20 \mathrm{~km}$ hosszan. A zarándokút további kialakításánál fontos szempont, hogy csatlakozási lehetőséget biztosítson a többi zarándokúthoz. Ezért Tokajig vezették el az utat, hogy ott rácsatlakozhasson a Mária Útra, amin keresztül különböző kereszteződéseken át el lehet jutni Budáig, majd pedig a Magyar Zarándokúton, illetve a Szent Jakab Uton egészen Pozsonyig.

\subsection{SZENT JAKAB ÚT}

A Magyarországon 2009-ben - korábbi El Camino-t járt zarándokok lelkesedéséból fakadt kezdeményezésre - alapított Szent Jakab Út fenntartója az utat a spanyolországi El Camino-val azonosítja. A Budapestről induló, Pannonhalmán és Lébényen átvezető, majd az országot Rajkánál elhagyó út csatlakozik az európai Szent Jakab Út hálózatához, így elviekben közvetlenül el lehet jutni Szent Jakab sírjához. A magyar szakaszt a spanyol Szent Jakab Út is elismeri, regisztrálta, feltünteti partnerei között. Érdekesség, hogy az út magát „egypofásnak” nevezi, azaz kizárólag egy irányba járható. Budapest felől került felfestésre az út jelzése, visszafelé ezért nem ajánlott a haladás.

A fó útvonal honlapon jelzett, magyar képviselók által fenntartott hossza Budapesttől Rajkáig $250 \mathrm{~km}$, alternatív útvonala pedig $210 \mathrm{~km}$, ami Tihanytól Rajkáig vezet, igaz, ebből önállóan (nem a fóuton) csak 109 km-t halad az út. Teljes hazai útvonala $460 \mathrm{~km}$, amely 50 esetben halad át valamely magyar településen, Pozsonyig számítva 523 km. Magyarországon végig jól jelzett, karbantartott útvonalról van szó.

\subsection{GYÖNGYÖK ÚTJA}

A 2006-ban indult Via Margaritarum (Gyöngyök Útja) zarándokút Mátraverebély-Szentkút és Mariazell között, illetőleg Budapest és Mátraverebély-Szentkút között halad. Az utat az út honlapja 760 km hosszúnak írja le, a kutatás azonban 740 km-t számolt térkép alapján, amelyból a magyarországi szakasz $558 \mathrm{~km}$. A rövidebb, csak hazai szakaszokat tartalmazó útvonal $189 \mathrm{~km}$ hosszan vezet a fóvárosból a kegyhelyre. Az út két hazai szakasza összesen 106-szor halad át valamely településen. Az útnak nincs hivatalos kezdőpontja, ám oklevelet elviekben csak az kaphat, aki ezt a teljes, 189 km-es utat teszi meg Budapestról. A mariazell-i oklevélhez pedig mindössze annyi a követelmény, hogy valahonnan Magyarországról induljon a zarándok.

A Gyöngyök Útja abban határolja el magát - az interjú során kimondottan is - a többi zarándokúttól, hogy itt sokkal tudatosabban jelenik meg a befelé figyelés és a lelki jelleg.

\subsection{MÁRIA ÚT}

A 2006-ban alapított Mária Út Közhasznú Egyesület által fenntartott Mária Út egy napjainkban is folyamatos fejlesztés, kijelölés alatt álló, saját maga meghatározása alapján „Közép-Európán átívelő zarándok- és turistaút-hálózat, melynek kelet-nyugati tengelye az ausztriai Mariazelltól az erdélyi Csíksomlyóig vezet" ${ }^{\prime \prime}$. Emellett egy észak-déli foótvonal is vezet, amely Magyarországon már jól kijelölt, a határon túli területek azonban még javában fejlesztés alatt vannak. A cél, hogy az útvonal rajzolata idővel egy Közép-Európát átölelő keresztet adjon a térképen.

A Mária Út már jelzett vagy legalább térképen kijelölt hazai szakaszai megközelítőleg 2238 km-t tesznek ki, ám csaknem további 400 $\mathrm{km}$ kijelölése és jelzése várható. Az úton, nemzetközi szinten (a hazai szakaszokat is beleszámítva) 5209 km-nyi Mária Út érhető el, ám öszszesen $8957 \mathrm{~km}$ elérése várható, ha az összes már most ismert fejlesztési terv megvalósul.

\subsection{MAGYAR ZARÁNDOKÚT}

Míg a Szent Jakab Út magát az El Camino-val azonosítja, addig a Magyar Zarándokút - a fenntartó elmondása alapján - „teljes egészében a spanyolországi El Camino mintájára épült ki, és múködik, ugyanabban a rendszerben".

Az út észak-déli irányban országhatártól országhatárig (Esztergom - Máriagyúd) szeli át Magyarországot. Esztergomból indulva a Pilisen, majd Budapesten keresztül a Duna völgyében halad, majd Szekszárd és Baja térségében elkanyarodik a Mecsek felé, és Pécsen keresztülvezetve érkezik meg Máriagyúdre. A jelenleg jelzett magyarországi foútvonal $431 \mathrm{~km}$-t tesz ki, ami a leágazásokkal, alternatív útvonalakkal együtt nagyjából 600 km-re bővül. Az út Magyarország eddigi egyetlen kizárólag hazai útja volt, azonban most egy határon átnyúló IPA-projekt keretében sikerült meghosszabbítani. Így már hivatalosan átmegy Horvátországba is, megközelítőleg $100 \mathrm{~km}$-en át, azonban ennek útvonala egyelőre nem elérhető. Emellett megkez-

6 http://mariaut.hu/tart/farticle/1377/57/1 


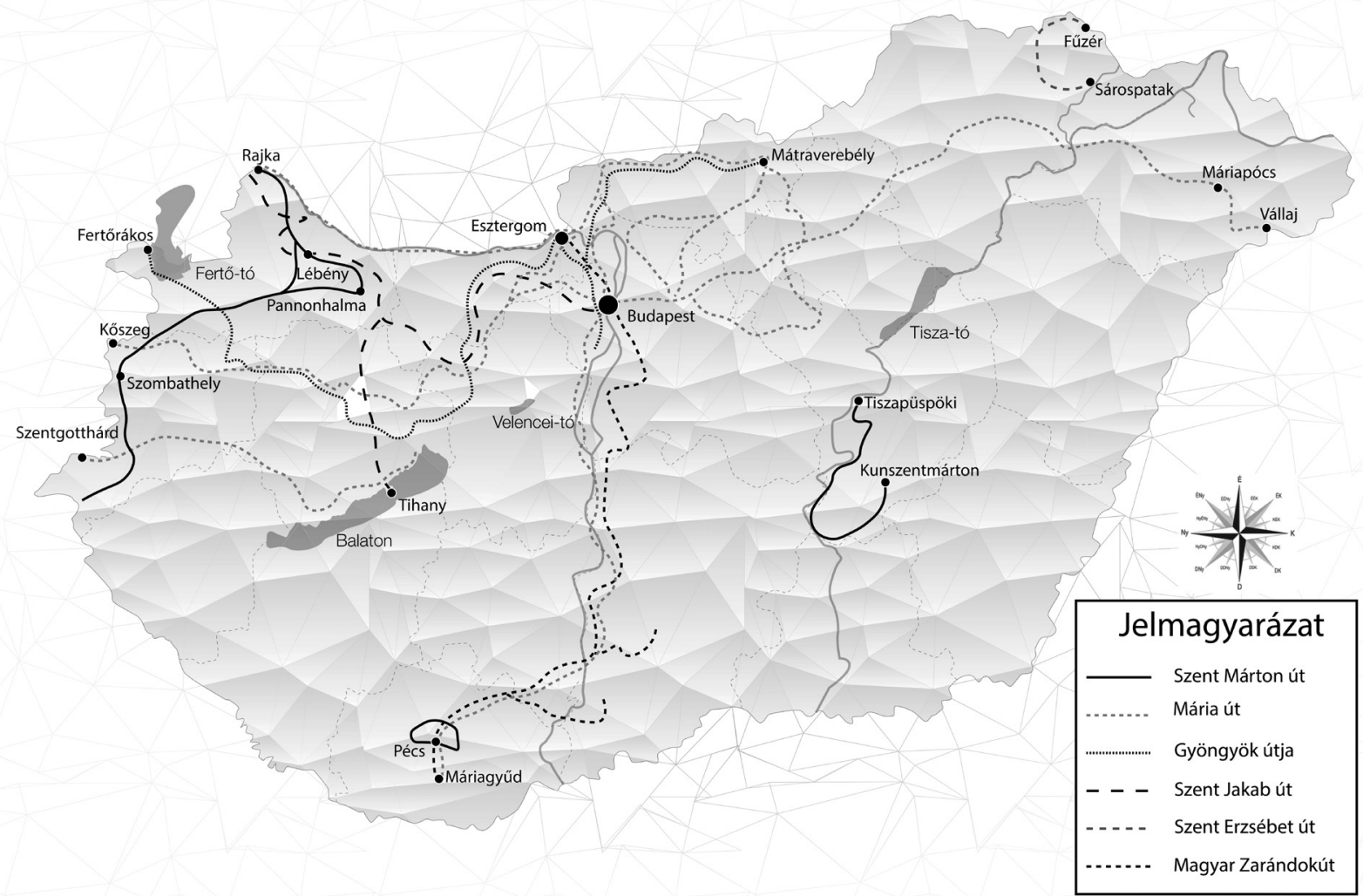

Forrás: saját szerkesztés

dődött az előkészülete egy nyugat-magyarországi útvonalnak is Budapest - Balaton - Szekszárd útvonalon (3. ábra).

A hazai zarándokutak háttérintézményei az elmúlt évtizedben alakultak és fejlődtek jelenlegi intézményesültségi szintjükre, így nem meglepő, hogy - egy zarándokút kivételével maguk is vallják - még nem értek el a professzionalizmus szintjére, így az önmagukról való pontos tényadatgyújtés is esetleges, mérsékelten elvárható.

Minden út nyitott a katolikustól eltéró felekezetek jelenlétére is. Önmagát általában minden út legalább keresztényként határozza meg. Olykor konfliktust, rosszallást okoz az egyházi képviselők részéről, hogy egy-egy út nem képviseli markánsan a katolikus értékeket, vagy hogy egyegy zarándok egyértelmúen nem vallásos, nem viselkedik ennek megfelelően. Más klerikus megszólaló a megkérdezettek közül ugyanakkor pasztorációs lehetôséget lát mindebben.

\section{Keresleti tényezók}

\subsection{LÁTOGATÓSZÁM ÉS REGISZTRÁCIÓ}

"A franc tudja..., mert ugye véletlenszerúen találkozol azzal, Te most itt volt három francia gyerek, most itt volt két német."

Az útvonalon elindulók száma vagy akár regisztrációja általános probléma (4. ábra). A jelenlegi nyilvántartások esetlegessége, sokfélesége miatt lehetetlen megállapítani, pontosan hány fő, főleg hány napot tölt évente a különböző zarándokutakon. Általában csak azokról van tudomásunk, akik vagy az út saját szervezésú programjain vesznek részt, vagy bejelentik a fenntartónak az úton való indulásukat, jelenlétüket, ám a bejelentő regisztrációja ez esetben is kétséges. A zarándokút végig járása, a kiindulóponttól a végpontig való eljutás sokszor nem is egy etapban történik, hanem szakaszolva, akár több évre elosztva. 
Múhely

4. ábra

Zarándokutak becsült/regisztrált látogatószáma

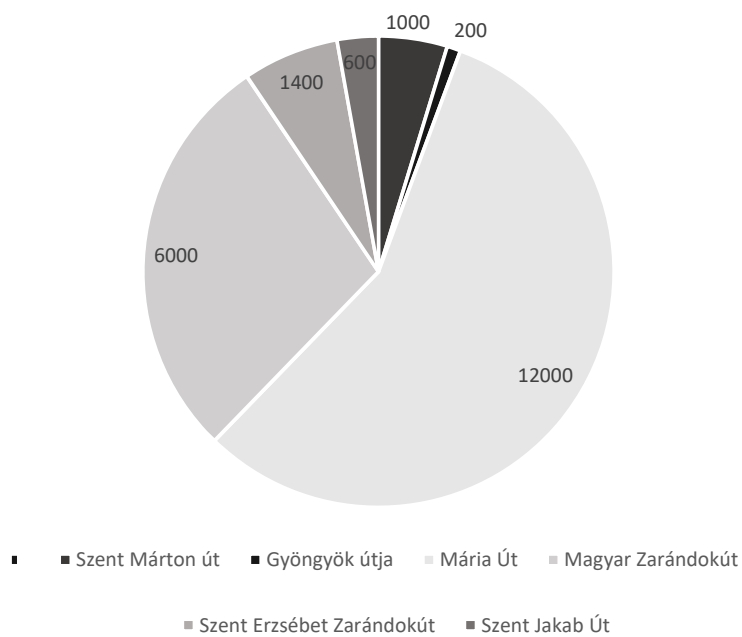

Forrás: saját szerkesztés

Kérdésünkre a fenntartók sokszor csak a megérzésekre támaszkodva reagáltak. Ezen homályos adatok alapján alapvetően évi 8-10 ezer főre saccolható az utakon valamilyen, egy napnál hosszabb távot megtevők száma, ám ez tényadatokkal jelen helyzetben nem támasztható alá.

\subsection{MOTIVÁCIÓK ÉS TERVEK}

„Mondjuk rá, 85-90 százalékba' az motiválja az embereket, hogy vagy valami kérnivalója van, vagy valami hálát kell adni."

Külön kérdésben foglalkoztunk azzal a kutatás során, hogy a fenntartók tapasztalatai szerint mi motiválja a résztvevőket a zarándoklatra. A következők merültek föl (2. táblázat)

\subsection{TERÜLETI KONCENTRÁCIÓ ÉS SZEZONALITÁS}

„Novemberbe' Szent Márton túrák (vannak). ... Most például a szlovén határon lesz egy ilyen... Domonkosfánál, egy túra, amelyre mennek tôlünk is."

Területi koncentráció tekintetében általános fenntartói vélemény, hogy az adott zarándokútnak elsósorban a fó útvonala az, ahová a résztvevók relatív, de akár túlnyomó többsége érkezik. Tapasztalataik szerint a mellékútvonalak ritkábban jártak, de egy út esetében elófordul az is, hogy a fenntartó tudatosan nem foglalkozik mással, mondván, ô csak a fốútvonallal szeretne foglalkozni, a többit pedig hagyja, hogy önkéntes alapon múködjön, ahogy tud, mert az energiáját és idejét egy irányba szeretné fókuszálni. Szezonalitás tekintetében az időjárás dimenziója a legmeghatározóbb: magasabb a résztvevők száma tavasztól kora ôszig, illetve napos idő esetében, főképpen nyáron. A másik dimenzió az ünnepkörhöz kötődés, amely fóleg a szentekról elnevezett utak esetében fontos.

\section{A zarándokok általános és zarándokút specifikus motivációi}

\begin{tabular}{|c|c|c|}
\hline & Általánosan megjelenö & $\begin{array}{l}\text { Kutatásban megjelent egyéni motivációk } \\
\text { (interjúalanyok saját élménye) }\end{array}$ \\
\hline $\begin{array}{l}\text { Szent } \\
\text { Márton út }\end{array}$ & Szent Márton-tisztelet & $\begin{array}{l}\text { anya-lánya kapcsolat megélése kettesben; elsóként } \\
\text { járta be a Szombathely-Tours utat } 70 \text { nap alatt; } \\
\text { tesztelni, hogy megfelelö-e a kijelölt út }\end{array}$ \\
\hline $\begin{array}{l}\text { Gyöngyök } \\
\text { útja }\end{array}$ & $\begin{array}{l}\text { mókuskerékból való kilépés, befelé fordulás, Isten } \\
\text { keresése }\end{array}$ & $\begin{array}{l}\text { El Camino után itthon is szeretett volna menni } \\
\text { valahova }\end{array}$ \\
\hline Mária Út & $\begin{array}{l}\text { rövid időre kiszállás a "taposómalomból", megújulás, } \\
\text { élmény, tragédiát megéltek feldolgozási igénye, vallási } \\
\text { ok, teljesítményorientáció }\end{array}$ & gyerekkel közös élmény \\
\hline \begin{tabular}{|l|} 
Magyar \\
Zarándokút
\end{tabular} & $\begin{array}{l}\text { vallási-spirituális célzat, személyes gondok, fizikai } \\
\text { teljesítmény, „különösebb ok nélküliség” is megjelent }\end{array}$ & $\begin{array}{l}\text { ismerôs zarándok utolsó napi szakaszon való } \\
\text { elkísérése }\end{array}$ \\
\hline $\begin{array}{l}\text { Szent } \\
\text { Erzsébet } \\
\text { Zarándokút }\end{array}$ & $\begin{array}{l}\text { Szent Erzsébet-tisztelet; túlhajszoltságból való } \\
\text { kilépés; életproblémák feldolgozása; önmagukra való } \\
\text { idôráfordítás }\end{array}$ & szülók egykori házasságkötési helyének felkeresése \\
\hline $\begin{array}{l}\text { Szent Jakab } \\
\text { Út }\end{array}$ & $\begin{array}{l}\text { El Camino hazai járása, ne kelljen odáig elmenni; } \\
\text { spirituális élményszerzés; kiszakadás a hétköznapokból, } \\
\text { a „szolgáltatások világából”; lelki töltekezés }\end{array}$ & teher-letétel, fordulópont az életben \\
\hline
\end{tabular}

7 Mind az általánosan megjelenő, mind pedig a kutatásban megjelent egyéni motivációk alacsony említés és mintaelem száma nem teszi lehetővé a prioritási sorrend felállítását. 


\section{Szálláshelyek}

„Van egy szálláshely, aztán vagy kihasználjuk, vagy nem. Vagy... befogadjuk az autópálya építóket."

Alapvetően minden zarándokút foútvonalán már „kiépített” szálláshelyek és ezek listája várja a zarándokokat, ám a mellékútvonalakon ez még nem minden fenntartónál megoldott.

Eleve ebból a célból épuilt zarándokszállást csak elvétve találunk a zarándokutak kínálatában, azokat is fóleg kegyhelyek körül. Valamivel több „zarándokszállás” címkével ellátott bérelhető, igénybe vehető ingatlan is felmerül az utak kínálatában. Ezek általában, de nem kizárólag plébániákat, azok helyiségeit, önkormányzati ingatlanokat, vagy magánszállásokat jelentenek. Nem ritka, hogy a fenntartók a kapacitásbővítés okán, vagy mert nincs más lehetőség, üzleti (kereskedelmi) szálláshelyekkel is fölveszik a kapcsolatot.

Egy-egy úton számos szálláshelytípus található meg a legpuritánabb megoldásoktól kezdve a 3, 4, 5 csillagos panziókig és szállókig bezárólag. Emiatt az árképzés is igen eltéró. Fenntartói adatok alapján 1000-5000 forint között alakulnak az átlagárak, egyegy kiugró árú vagy épp becsületkasszás szálláshelyet leszámítva. A saját kérdőíves kutatás 4058 Ft-os bruttó átlagárat állapított meg (szobaár/éj) a 84 érvényes választ adó szállásadóink válaszai alapján.

\section{Turisztikai potenciál}

„Ugye most terjed ez a slow turizmus, tehát hogy, hogy szánjunk időt az élmények átélésére!"

A zarándokút-fenntartók szerint egyértelmú, hogy a zarándokút (a zarándokok napi étkezése, szállása, illetve az út fejlesztésére nyert pályázati összegekból végzett felújítások révén) többé-kevésbé hozzájárul a helyi turizmus, ezzel együtt a gazdaság, de fóképp az infrastruktúra fejlődéséhez (3. táblázat).

A fenntartók körében egészen vegyes a zarándokutak turisztikai hasznosításának megítélése. Egyesek kifejezetten várják, remélik az állami turisztikai „,beavatkozást”, másfelól több út aggódva tekintene bármilyen jellegú turisztikai intervencióra. Általános igény mindkét csoport részéról a beavatkozásokat megelóző aktív párbeszéd kezdeményezése.

Általános fenntartói vélemény, hogy a hazai zarándokutak hozzájárulhatnának a Magyarországról kialakult imázs erősítéséhez. Mindennek mérése rendkívül problematikus, tekintve, hogy nem tudják maguk a fenntartók sem pontosan, valójában milyen létszámban vannak jelen útjaikon a magyar, illetve külföldi zarándokok. Emellett kellő forrás, valamint professzionalizmus hiányában csak elhanyagolható arányban lehetséges a fenntartók által említett helyi kulturális, gasztronómiai és népi nevezetességek értékesítése.
3. táblázat

A zarándoklat során turisztikai szolgáltatások igénybe vétele

\begin{tabular}{|l|l|}
\hline $\begin{array}{l}\text { Szent } \\
\text { Márton út }\end{array}$ & $\begin{array}{l}\text { fóleg Szent Mártonhoz köthetó múzeumok, } \\
\text { múemlékek, az állomások kulturális, } \\
\text { népmúvészeti, gasztronómiai attrakciói }\end{array}$ \\
\hline $\begin{array}{l}\text { Gyöngyök } \\
\text { útja }\end{array}$ & $\begin{array}{l}\text { csak, ha az út közvetlenül érinti és idó, energia } \\
\text { marad rá: egy-egy vár, konkrétan állomásként } \\
\text { említ egy Weöres Sándor-kiállitást }\end{array}$ \\
\hline Mária Út & $\begin{array}{l}\text { Fenntartói észrevétel alapján a zarándokok } \\
\text { nem vesznek igénybe turisztikai } \\
\text { szolgáltatásokat zarándokként, ám utólag } \\
\text { előfordulhat, hogy visszatér egy-egy } \\
\text { helyszínre, mint turista }\end{array}$ \\
\hline $\begin{array}{l}\text { Magyar } \\
\text { Zarándokút }\end{array}$ & $\begin{array}{l}\text { múzeumok, müemlékek } \\
\text { Szent } \\
\text { Erzsébet } \\
\text { Zarándokút Szent Erzsébethez köthetố múzeumok, } \\
\text { fúemlékek, az állomások kulturális, } \\
\text { népmüvészeti, gasztronómiai attrakciói }\end{array}$ \\
\hline $\begin{array}{l}\text { Szent Jakab } \\
\text { Út }\end{array}$ & $\begin{array}{l}\text { csoportos zarándoklat alatt kizárólag kulturális } \\
\text { turizmus merül föl, abban az esetben, ha nem } \\
\text { kell érte különösebben letérni az útról, és akinek } \\
\text { még van hozzá ereje }\end{array}$ \\
\hline
\end{tabular}

Forrás: saját szerkesztés

Általános, de nem minden megszólaló körében elfogadott narratíva a turisztikai célú fogyasztás elkerülésének szándéka. Ebból a szempontból határ húzható a zarándokszolgáltatók két csoportja közé: akik megengedhetônek tekintik az önfenntartáshoz szükségesen felüli fogyasztást, illetve akik ezt a magatartást tudatosan elutasítják. Ha a zarándokút-fenntartónak nem kifejezett célja a kulturális, gasztronómiai örökség bemutatása, akkor általában nem szempont a fogyasztásra ösztönzés, legfeljebb közvetlenül az úton elhelyezkedő kulturális jelentőségú desztinációk meglátogatására van lehetőség.

\section{8. Üzemeltetési modell}

„A nemzetközi az úgy fog összeállni, hogy mivel van Szlovákiában és Erdélyben már külön egyesület, és van készülóben az osztrákoknál is, (...) létre fogjuk hozni, a terv megvan."

A hazai zarándokút-fenntartók mindegyike bejegyzett civil-nonprofit szervezet. Öt egyesületi formát, egy pedig alapítványi formát vett föl. Fizetett alkalmazottja egyik szervezetnek sincs, a legtöbb munkát önkéntes jelleggel végzik, ám egyes utak esetében átfedések figyelhetők meg, azaz valamely, a zarándokúthoz kapcsolódó intézmény munkatársa(i) a zarándokúthoz kötôdő operatív, adminisztrációs vagy szervezési feladatokat is ellátják a munkakörükön belül. 
A hazai zarándokutak többségének nincs lehetősége sem önálló irodát, sem külön számítógépet, telefont fenntartani a szervezéshez. Tevékenységükhöz általában munkahelyeik erőforrásait, illetve saját számítógépeiket, telefonjaikat használják. A kérdésre válaszolva közel minden alany kifejtette, hogy bár a jelen állapot fenntartható ebben a formában, a komolyabb fejlődéshez szükséges volna egy önálló helyiség, illetve kizárólag az úttal foglalkozó munkatárs alkalmazása.

A döntéshozatali mechanizmus rendkívül egyszerú minden szervezetnél. Hivatalosan az egyesületek elnökségei, valamint az egyesületek közgyúlése, illetve az alapítvány kuratóriuma hozza meg a legfontosabb döntéseket, amelyeket aztán vagy delegálnak az önkénteseknek, vagy velük együtt, a feladatokat szétosztva hajtanak végre.

A hazai zarándokutak lényegében nem rendelkeznek lefektetett sikertényezókkel, siker-indikátorokkal. Erról a kérdésról az interjú kapcsán gondolkodtak el először, mindazonáltal közös válasznak tekinthető az „igényekre való sikeres reakció".

\section{Fejlesztési javaslatok}

„Ha én lennék (a turisztikai beavatkozásért felelős személy), akkor ezt nagyon óvatosan kezelném. És nagyon erôsen kommunikálva partnerként az egyesületekkel."

A fejlesztési javaslatok tartalmaznak egyedi, kizárólag csak az adott zarándokutat érintő véleményeket, illetve általános megfogalmazásokat a magyarországi zarándokút hálózat tekintetében.

\subsection{EGYEDI FEJLESZTÉSI JAVASLATOK}

Csak két út fenntartója fogalmazott meg helyi, adott állomásra vonatkozó fejlesztési célokat, vágyakat. Ilyen volt például: patak fölötti gyalogos híd újjáépítése, látogatóközpontba alkalmazott felvétele, helyi zarándokszállás kiépítése 50 meghatározott településen. Az adott zarándokútra, szakaszra vonatkozó igények között minden út esetében egyértelmúen megjelenik a fizetett alkalmazott felvételének és egy iroda múködtetésének a lehetôsége. Az egyik zarándokút bécsi vagy pozsonyi információs „bázis” kiépítését, fejlesztését is szeretné elérni.

\subsection{A HAZAI ZARÁNDOKUTAK EGÉSZÉRE VONATKOZÓ FEJLESZTÉSI JAVASLATOK}

A zarándokutak üzemeltetői részéről:

- profi marketing elérése és közös fellépés turisztikai kiállításokon,

- közös arculat, közös honlap kérdése,

- egységes kritériumrendszer,
- zarándokszállások egységesítésének kérdése (nincs teljes egyetértés a fenntartók és szakértơk körében), közös adatbázis, külön minőségi megjelölés igénye,

- az idegenvezetôi minôsítés jogi helyzetének tisztázása a zarándokút-vezetők körében (jelenleg kérdéses, hogy idegenvezetői végzettséggel nem rendelkezó fenntartók vezethetnek-e zarándokutat),

- jelzések, információs táblák kihelyezése szerte az országban iránymutató és edukációs céllal,

- közös, kedvezményekre jogosító „zarándokkártya” készítésének igénye,

- szezonalitás kiküszöbölése különböző (állami) kedvezményekkel, hogy ne csak meleg időben járják a zarándokutakat, hanem késő ősztôl kora tavaszig is,

- papok, klerikusok felmentése plébániai teendőik alól zarándokutak lelki vezetése céljából,

- útvonalszakaszok tematizálása, fóleg a hosszabb utak esetében, hogy egy-egy rövidebb szakasz bejárása is teljes élményt biztosítson,

- közép-európai zarándokhálózat kialakítása.

A fókuszcsoportok résztvevői részéről:

- Több kommunikációra, nagyobb reklámra lenne szükség.

- Felmerült ötletként a mobil applikációk fejlesztése, információkkal, térképpel, szálláshelyekkel.

- A kölcsönös bizalom és biztonságérzet fejlesztése érdekében a települések lakóit is be kellene vonni, amelyeken keresztül mennek a zarándokutak.

- Magyarországnak időre van szüksége, hogy ezeknek az utaknak a jelentősége megerősödjön, az infrastruktúra kialakuljon, és az emberek életében is szokássá váljon a zarándoklat.

Mind az üzemeltetők, mind pedig a fókuszcsoport résztvevői részéről megfogalmazásra került, hogy a jelenlegi kaotikus és sokszor ellentétekkel átszőtt, nem egységes hálózatot alkotó rendszer fenntarthatatlan. A szabályozás, az üzemeltetési modell nem alkalmas arra, hogy pénz áramoljon a szektorba, és ezzel fejlesztések valósulhassanak meg.

Az üzemeltetők megfogalmazása szerint a zarándoklat szakrális mivoltának megórzése az egyik legfontosabb cél, nem szabad, hogy a zarándoklatok elüzletiesedjenek. Az állami beavatkozás szükségességét sok esetben kétkedve kezelik.

Ezzel ellentétben megfogalmazásra kerültek különböző fejlesztési célok, a bevételek növelése, és a jogi szabályozás kialakítása. Ezen kívül, közös zarándokút rendszer kialakítása, egységes kritériumrendszer kialakítása, illetve közös marketingtevékenység, amellyel a célszegmensek elérhetóvé válnának.

Ez a két cél jelen helyzetben összeegyeztethetetlen. Ezen kívül, amennyiben a fejlesztési elvárások és marketingtevékenységek plusz vendégforgalmat 
generálnak, gondot okozna a minőségi látogató-menedzsment megoldása. A szektor még a jelenlegi helyzetet is csak nehézségek árán tudja kezelni, nem képes egy igényes, tudatos és szolgáltatásorientált kibővült kereslet megfelelő színvonalon történő fogadására.

Jelenleg ellentétek és célkülönbségek mutatkoznak, mind az egyházi, mind a világi elképzelések között. Ahhoz, hogy a zarándokturizmus meg tudja őrizni szakrális mivoltát, ezen kívül megfelelő szolgáltatást tudjon biztosítani a résztvevőknek, ezeket az ellentéteket fel kell oldani, és egy közös álláspontot kell kialakítani, különben a zarándokutak nem tudnak kikerülni ebből a kilátástalan körfolyamatból.

Összességében elmondható, hogy a zarándokturizmus a következó években különösen fontos szerepet kaphat a hazai turizmusban, hiszen a nemzetközi és a hazai turisztikai trendek - mint az egészségtudatos utazás, az egyedi élményígéretek fontossága - megfelelnek a zarándokturizmus jellegének. Ugyanakkor fontos tudni, hogy közös álláspont és fejlesztési koncepció kialakítása nélkül konzerválódik a jelenlegi helyzet. Amennyiben megszületik a részben világi, részben egyházi konszenzus a zarándokutak fenntartói részéról, egy jól múködtethető, turizmus-ágazat-barát, országimázs építő és nemzetmegtartást segítő egyedi turisztikai termékkel bővülhet a hazai turisztikai piac kínálata.

\section{Bibliográfia}

ALSTON, W. P. (1991): Perceiving God: The Epistemology of Religious Experience. Cornell University Press.

BAUMAN, Z. (1999): Turisták és vagabundok. Lettre. 35. 1999/Tél.

BAUMAN, Z. (2005): A munkaetikától a fogyasztás esztétikájáig. Replika. 51-52. pp. 221-237.

CASTELLS, M (2005): A hálózati társadalom kialakulása Az információ kora. Gazdaság, társadalom és kultúra I. kötet. Gondolat - Infonia, Budapest.

CASTELLS, M. (ed) (2004): The Network Society. A Crosscultural perspective. Cheltenham and Northampton, MA: Edward Elgar.

COHEN, E. (1992): Pilgrimage centers: concentric and excentric. Annals of Tourism Research. 19(1). pp. 3350.

DIGANCE, J. - CUSACK, C. (2002) Glastonbury: a tourist town for all seasons. In: Dann, G. M. S. (ed.): The Tourist as a Metaphor of the Social World. CABI, Wallingford, UK. pp. 263-280.

EADE, J. (1992): Pilgrimage and tourism at Lourdes, France. Annals of Tourism Research. 19(1). pp. 18-32.

GIURATI, P. - MYERS, P. M. G. - DONACH, M. E (1990): Pilgrims to "Our Lady of the Snows" Belleville, Illinois in the Marian Year: 1987-1988. In: Rinschede, G. - Bhardwaj, S. M. (eds.): Pilgrimage in the United States. Berlin: Dietrich Reimer Verlag. pp. 149-192.
GRABURN, N. H. H. (1983): The anthropology of tourism. Annals of Tourism Research. 10(1). pp. 9-33.

GUPTA, V. (1999): Sustainable tourism: learning from Indian religious traditions. International Journal of Contemporary Hospitality Management. 11(2/3). pp. 91-95.

GYORGYOVICH M. - PILLÓK P. (2014): A vallásos fiatalok társadalmi státuszának változása. Vigilia. 79(9). pp. 650-660.

HÁMORI Á. - ROSTA G. (2011): Vallás és ifjúság. In: Bauer B. - Szabó A. (szerk): Arctalan (?) Nemzedék: Ifjúság 2000-2010. NemzetiCsalád-ésSzociálpolitikai Intézet, Budapest. pp. 249-262.

HÁMORI, Á. - ROSTA, G. (2014): Declining Religiosity among Hungarian Youth after the Turn of the Millenium - Main Trends and Possible Explanations. In: Sepsi E. - Balla P. - Csanády M. (szerk): Confessionality and University in the Modern World - 20th Anniversary of „Károli” University. Studia Caroliensia. L'Harmattan Kiadó, Budapest. pp. 322-338.

HUNT, E. D. (1984): Travel, tourism and piety in the Roman Empire: a context for the beginnings of Christian pilgrimage. Echos Du Monde Classique. 28(3). pp. 391-417.

INGLEHART, R. - WELZEL, C. (2005): Modernization, Cultural Change and Democracy. The Human Development Sequence. Cambridge University Press.

INGLEHART, R. (1997): Modernization and postmodernization. Cultural, Economic, and Political Change in 43 Societies. Princeton University Press, New Jersey, USA.

JACKOWSKI, A. - SMITH, L. V. (1992): Polish pilgrimtourists. Annals of Tourism Research. 19(1). pp. 92-106.

KISS M. (2015): A "turisztikai táj" kollektív megteremtése és fönntartása. Doktori $(\mathrm{PhD})$ értekezés. Szociológia és Társadalompolitika Intézet, Budapesti Corvinus Egyetem, Budapest.

KNUDSEN, B. T. - WAADE, A. M. (2010): Performative Authenticity in Tourism and Spatial Experience: Rethinking the relation between travel, place and emotion in the context of cultural economy and emotional geography. In: Knudsen, B. T. - Waade, A. M. (eds): Re-investing Authenticity: Tourism, Place and Emotions. Channel View Publications, Leeds. pp. 1-19.

KOLLÁR D. - KOLLÁR J. (2017): Tulajdonságok nélküli társadalom. Új jel-kép: kommunikáció, közvélemény, média. 3. pp. 36-44.

KOLLÁR D. (2017): Értékrendszer az információs társadalomban. In: Füstös L. - Tárnok O. (szerk): A változó értékrendszer. Társadalmi Elemzések Alkalmazott Múhelye, Budapesti Corvinus Egyetem, Budapest. http://team.gkar.uni-corvinus. hu/node/159, Letöltve: 2018. február 15.

KORPICS M. (2003): Egy zarándokhely átalakulásának vizsgálata turizmuskutatáson keresztül. In: Fejős Z. - Szijártó Zs. (szerk): Helye(in)k, tárgya(in)k, képe(in) 
k. A turizmus társadalomtudományos magyarázata. Tabula könyvek 5. Néprajzi Múzeum, Budapest. pp. 108-121.

KORPICS M. (2009): A zarándoklat mint a szakrális kommunikáció egy színtere. Doktori (PhD) értekezés. Nyelvtudományi Doktori Iskola, Pécsi Tudományegyetem, Pécs.

KSH (2016): Jelentés a turizmus és vendéglátás 2016. évi teljesítményéről. http://www.ksh.hu/docs/hun/ xftp/idoszaki/jeltur/jeltur16.pdf, Letöltve: 2018. február 2.

KULCSÁR N. (2015): A fogyasztói érték és az élmény kontextusa a turisztikai szakirodalomban. Vezetéstudomány. 46(3) pp. 18-25.

LAMBERT, Y. (1994): La religion: un paysage en pleine évolution. In: Riffault, H. (ed): Les valeurs des Français. Paris. pp. 123-162.

LUCKMANN T. (1996): A láthatatlan vallás. A vallás fenomenológiája. Lettre. 23. 1996/Tél.

MASLOW, A. H. (1943): A theory of human motivation. Psychological Review. 50(4). pp. 370-396.

MESTER T. (2006): Vallási turizmus. Turizmus Bulletin. 2. pp. $16-18$.

MINTEL (2005): Religious Tourism. Mintel International Group Ltd., London.

MINTEL (2012): Religious and Pilgrimage Tourism. Mintel International Group Ltd., London.

PETE ZS. (2016): Vallás és társadalmi struktúra. Szakdolgozat. Pázmány Péter Katolikus Egyetem Bölcsészet- és Társadalomtudományi Kar.

PINE, B. J. - GILMORE, J. H. (1999): The Experience Economy. Harvard Business Review Press. Boston, Massachusetts.

PINE, B. J. - GILMORE, J. H. (2007): Authenticity: What Consumers Really Want. Harvard Business Review Press. Boston, Massachusetts.

PUCZKÓ, L. -SMITH, K. M. (2009): HealthandWellness Tourism. Elsevier/Butterworth-Heinemann.

PUSZTAI B. (2000): Remény és beteljesülés. Utaslevelek a turizmus kutatásában. In: Fejős Z. - Szijártó Zs. (szerk): Turizmus és Kommunikáció. Budapest-Pécs, Tabula könyvek, Néprajzi Múzeum - PTE Kommunikációs Tanszék. pp. 180-190.

PUSZTAI B. (szerk) (1999): Szent és profán között. A szeged-alsóvárosi búcsú. JATE Néprajzi Tanszék, Szeged.

RAFFAY Á. - LŐRINCZ K. - CLARKE, A. (2013): Spirituális és üzleti értékek találkozása a vallási turizmusban. Turizmus Bulletin. 15(2). pp. 34-42.

RECULTIVATUR (2013): Termékfejlesztés „Lelkigyakorlatos központ létrehozása” - I. Ütem, ICG Ex Ante Tanácsadó Iroda.

RECULTIVATUR (2013b): SWOT Analysis. Religious Tourism. Training needs and population wider attitude in Hungary. ICG Ex Ante Tanácsadó Iroda.
RINSCHEDE, G. (1990): Religionstourismus. Geographische Rundschau. 42(1). pp. 14-20.

RITZER, G. (1999): Enchanting a disenchanted world: revolutionizing the means of consumption. Pine Forge Press.

RITZER, G. (2004): The McDonaldization of Society. SAGE Publications.

ROSTA G. (2011): Vallásosság a mai Magyarországon. Vigilia. 76(10). pp. 741-750.

RUSSELL, P. (1999): Religious travel in the new Millennium. Travel $\mathcal{E}$ Tourism Analyst. 5. pp. 39-68.

SCHLEHE, J. (1999): Tourism to holy sites. International Institute for Asian Studies Newsletter. 19:8.

SMITH, V. L. (1992): Introduction: the quest in guest. Annals of Tourism Research. 19(1) pp. 1-17.

SULYOK J. - MÁRTONNÉ M. K. (2014): A vallási turizmus helyzete Magyarországon. Turizmus Bulletin. 16(1) pp. 11-20.

SZENTE K. (2010): Miért jó egy zarándokút önkormányzati szempontból? In: Filepné Kovács K. (szerk): A Mária út hálózat és kialakítása. Budapesti Corvinus Egyetem, Tájtervezési és Területfejlesztési Tanszék, Budapest. pp. 89-94.

TAYLOR, C. (2007): A Secular Age. Harvard University Press.

TIMOTHY, D. J. - OLSEN, D. H. (2006): Tourism and religious journeys. In: Timothy D. J. Olsen D. H. (eds): Tourism, Religion and Spiritual Journeys. Routledge. pp. 1-21.

TOFFLER, A. (1970): Future Shock. Random House.

TOMKA M. (2010): Vallási helyzetkép. In: Rosta G. - Tomka M. (szerk): Mit értékelnek a magyarok? Faludi Ferenc Akadémia, Budapest. pp. 401-425.

TRONO, A. (2015): Religious tourism and pilgrimage management: an international perspective. In: Raj, R. - Griffin, K. (eds): Politics, policy and the practice of religious tourism. CABI, Wallingford, UK. pp. 16-36.

VUKONIC, B. (1992): Medjugorje's Religion and Tourism Connection. Annals of Tourism Research. 19(1). pp. 79-91.

VUKONIC, B. (1999) Catholic Pilgrimage: The Phenomenon of Medugorje. East-West Church $\mathcal{E}$ Ministry Report. 7(4). pp. 1-3.

WEBER M. (1982): A protestáns etika és a kapitalizmus szelleme: válogatott szociológiai irások. Gondolat, Budapest.

WEBER M. (1987): Gazdaság és társadalom 1. Közgazdasági és Jogi Könyvkiadó, Budapest.

WEBER M. (1992): Gazdaság és társadalom 2/1. Közgazdasági és Jogi Könyvkiadó, Budapest.

WEBER M. (1995): A tudomány és a politika mint hivatás. Kossuth, Budapest. 